\title{
THE MODEL FOR PUBLIC TELEVISION AND THE YOUNG AUDIENCE'S EXPECTATIONS. DIFFERENCES BETWEEN GREAT BRITAIN AND SPAIN IN THE PERCEPTION OF QUALITIES AND OBLIGATIONS
}

\author{
El modelo de televisión pública y expectativas de la \\ audiencia. Diferencias entre Gran Bretaña y España en \\ la percepción de cualidades y obligaciones
}

Carlos López-Olano

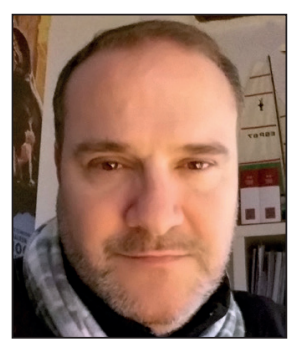

Carlos López-Olano is a lecturer in communication at the University of Valencia (UV). He has participated in MA and degree programs at the Jaume I University, Cardenal Herrera, and University of Virginia. He has been a visiting professor and researcher at the University of Roehampton (London) and University of Glasgow. He holds a PhD in Communication (2015) from the UV. He has worked as a journalist at Antena 3 and RTVV. He investigates public service media and transmedia. He is a member of the Mediaflows research group (CSO2016-77331-C2-1-R).

http://orcid.org/0000-0002-8121-5999

University of Valencia, Faculty of Communication Av. Blasco Ibáñez, 32. 46010 Valencia, Spain clolano@uv.es

\begin{abstract}
Public service media (PSM) are in crisis throughout Europe. As a scenario for research, the two extremes of the background have been chosen: the first, $B B C$, is at the heart of media system, has become a model for the others and has just finished the particularly delicate challenge of renewal the fundamental law that is to rule over the next ten years; the second is on the periphery of public television, and in the extreme circumstances in Spain that have driven some of the television corporations to extinction, such as Canal 9-Radiotelevisió Valenciana (RTVV). Using a method based on the use of semi-structured interviews and Delphi, the conception of these media models among their respective audiences is explored.
\end{abstract}

\section{Keywords}

Television; Public service media; BBC; RTVE; Television audience.

\section{Resumen}

Los medios de comunicación públicos están en crisis en toda Europa. Como escenario de la investigación, han sido elegidos dos extremos: el primero está en el corazón del sistema mediático, con la $B B C$ que se ha convertido en modelo para el resto, y que acaba de terminar su particular reto de renovar la ley fundamental que va a regirla durante los próximos once años; el segundo está en la periferia de la television pública, en unas circunstancias extremas en España que han llevado a algunas corporaciones a la extinción, como en el caso de Canal 9 - Radiotelevisió Valenciana (RTVV). Utilizando entrevistas semiestructuradas y Delphi, exploraremos estos modelos mediáticos entre sus respectivas audiencias.

\section{Palabras clave}

Televisión; Medios de comunicación públicos; BBC; RTVE; Audiencia de televisión.

López-Olano, Carlos (2017). "The model for public television and the young audience's expectations. Differences between Great Britain and Spain in the perception of qualities and obligations". El profesional de la información, v. 26, n. 4, pp. 714-721.

https://doi.org/10.3145/epi.2017.jul.15 


\section{Introduction. A model in crisis}

The context of this study is a public system of television that is in crisis. According to Richeri (1994), television corporations are being hit in three ways: a crisis of legitimacy, of financing, and of identity. Moreover, the recession extends from traditional television to multimedia platforms. What has come to be known as the transition from public service broadcasting (PSB) to public service media (PSM) has not exactly alleviated the situation: there exists strong pressure to downsize PSM organizations, limit investment options, and restrict online and digital operations (Lowe; Steemers, 2012). The danger has spread across Europe, where throughout the last century this form of media organization has become generalized and standard for the continent.

"The visibility and sustainability of national players, and therefore the national audiovisual industry, is endangered." (EBU, 2015, p. 7).

Others believe the problem is to be found in the origins of public television:

"PSBs in this country [UK] have paid a price for their state-sponsored privileges. That price has been their freedom." (Murdoch quoted in Barnett, 2011, p. 11).

But the historic process of the creation of European state media can be told very differently:

"In England, France and Germany, the media were organized as public or semi-public corporations because, otherwise, their public function would not have been sufficiently protected against their private-capitalist function" (Habermas, 1989, p. 215).

The crisis has taken shape from peripheries: the closure of the Greek television corporation, and the regional Radiotelevisió Valenciana in 2013, have been two exemplary, extreme cases

Although the cradle of public television is without a doubt to be found in Western Europe (Steemers, 1998), stemming from the original $B B C$, the model spread to all the confines of the continent. Indeed, the crisis has taken shape in these peripheries-for example, two closures in 2013 including one of a Greek television corporation and another of regional Radiotelevisió Valenciana. Although there are few references in the specialized academic bibliography about public television, some authors have highlighted closures as attacks on media freedom (Tambini, 2016; Freedman, 2016b).

The general crisis and the fragmented digital market cast shadows on public TV (Debrett, 2014). In Spain, Maurizio Carlotti, the high-ranking executive linked to the Atresmedia group and educated in the shadow of Silvio Berlusconi, has a similar opinion:

"A television, like it or not, is like a tavern, like a potato shop, like a factory... it has to make money. If you don't make money, you're weak; you can be blackmailed by

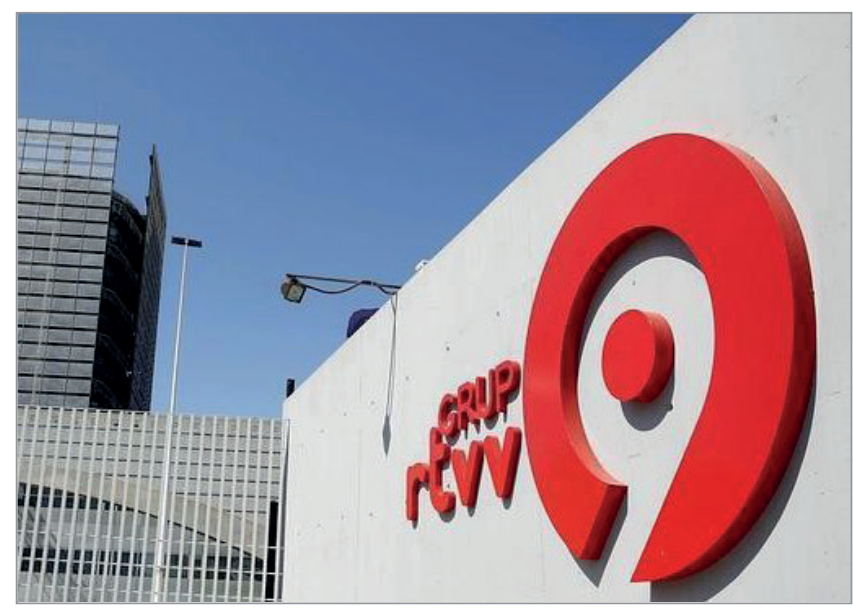

http://www.diesl.com/tag/rtvv

power. If you make money, you can look anyone in the eye"1 (Díaz, 2006, p. 373).

Consequently, the economic crisis has led to, at minimum, a drop in the power of public television, if not to extreme cases of closure (Sehl; Cornia; Nielsen, 2016). However, faced with pessimists, the British regulatory body, Ofcom, has stated that the television crisis has been exaggerated, and that in spite of the general perception, the United Kingdom's flagship news programs have upheld their share (Cushion, 2012).

\subsection{The renewal of the model in the United Kingdom}

The $B B C$ has not been indifferent to the crises, despite its intrinsic strength. The British broadcaster has been through many delicate moments throughout its history. In the past hundred years, there have been several controversies that stand out, such as the case of the radio on dealing with the strike of 1926, about which, for example, Schlesinger (1987) says that

"there is ample evidence [...] that the $B B C$ simply did as the government asked".

Among the most significant crises face by the BBC was one that arose in the eighties and nineties when Margaret Thatcher was Prime Minister. In the economic sphere, the theories of Managerialism were applied to the $B B C$, just as they were to the rest of the country (Tracey, 2014). Under the management of John Birt, a thousand employees were laid off, which would have been unthinkable previously. During this difficult time with Birt, which has been explained exceptionally by Born (2004), various attempts were made at governmental manipulation.

In spite of these and many other problems, various authors believe that the $B B C$ now faces the most important challenge in its history (Mair; Tait; Keeble, 2014). The multimedia conglomerate, which began in radio and later transitioned into a television corporation, has just renewed its Royal Charter, the fundamental law that regulates its model for the next eleven years. The renewal was due to be made after the Conservatives' repeat victory with David Cameron, which set the alarm bells ringing.

The referendum regarding the United Kingdom's staying in the European Union or not was about to change the calen- 
dar planned for renewal of the Royal Charter. A source at Westminster announced the White Paper, the government's final proposal to amend this fundamental law of the $B B C$ planned for the spring of 2016, was going to be delayed so that it would not interfere with the Brexit referendum (Martinson, 2016). In the end this was not the case, and this important document was presented. The schedule was carried out with the renowned British punctuality: in October the proposal was discussed in parliament, and the final legal text came into force on the $1^{\text {st }}$ of January, 2017.

Despite all of the predictions about minimizing the budget, the White Paper (Department for Culture, Media and Sport, 2016) and the Royal Charter surprisingly kept the economic conditions enjoyed by the corporation to date.

At least for the upcoming five years, the license fee shall be maintained and adjusted for inflation. The official text boasts that the $B B C$ is the most well-financed public broadcaster in Europe, with $£ 3.7$ billion out of a total budget of 5 billion, which is inline with these propitious times for British national self-affirmation. Clearly, an adequate budget means powerful in-house production and jobs being maintained.

As regards governance, the $B B C$ Trust disappears, with supervision of the broadcaster -including news programs and their independence- left in the hands of the external regulator Ofcom. The prior study by Sir Clementi (2016) proposed that Ofcom should directly take on its functions (2016). Although the measure was expected, it has not been without criticism (Freedman, 2016a). From now on there will only be a "unitary board in the $B B C$ ", at least half of whose members will be named by the $B B C$ itself.

\section{Various authors believe that the $B B C$ has now faced the most important challenge of its history}

Beyond other details of the renewal of $B B C$ that are without a doubt important, as the presence of Audience councils (Azurmendi; Muñoz-Saldaña, 2016), there is an essential dichotomy in the proposals: a PSM on the rise or falling back. And it appears that the British government has decided that, for now, it is not the time to have less $B B C$. This is opposite current trends, not only in the British audiovisual system, but also in the European one. Perhaps the complicated political situation, with an European plebiscite, finally caused the downfall of Cameron and has made the UK reluctant to face political erosion by reducing something that, according to what the surveys have made perfectly clear, remains a symbol of greatness for the British (Department for Culture, Media and Sport, 2015). If there is still something the UK can be proud of in this period of crisis, the wisest political thing to do is to not touch it.

\subsection{The television crisis in Spain}

Meanwhile, RTVE in Spain has not managed to climb out of the hole it has been in for so many years. The body began in 1956 in the midst of the Franco regime as a propaganda instrument for the latter, but above all as a means to fos-

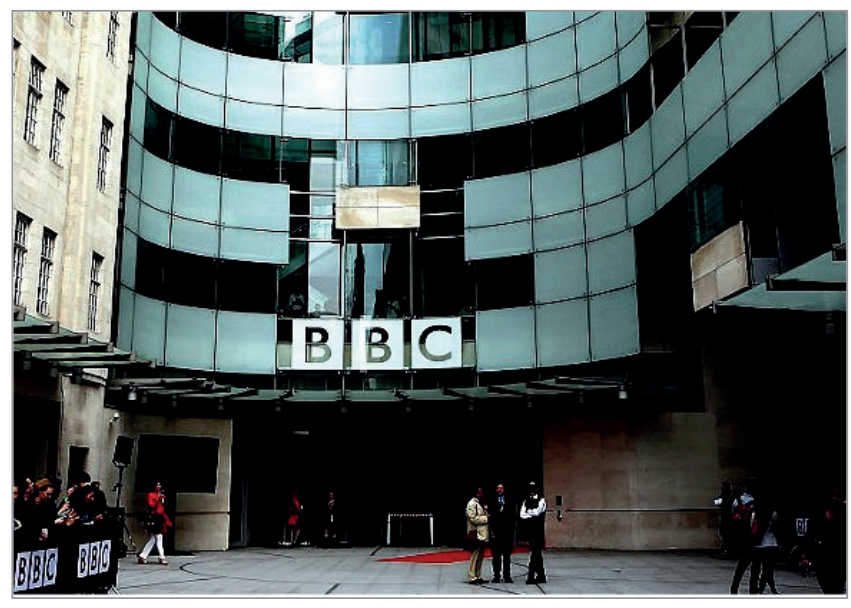

http://www.hrreview.co.uk

ter collective evasion (Rueda-Laffond; Chicharro-Merayo, 2006). It is an impossible task to compare it with the trajectory of the $B B C$. To illustrate the instability of $R T V E$, only a single number is necessary: from its conception until now, the corporation has had 29 general directors/presidents. At the $B B C$, there have been only 14 .

The situation was not solved when democracy arrived, and the deficit of independence of radio and television from the government was maintained (Bustamante-Ramírez, 2013a; Palacio, 2012). That was until 2006, when there was significant reinvestment in RTVE. Firstly, a labor force adjustment plan was implemented to reduce staff costs and balance the accounts, and the regulatory framework was overhauled in Spain. The creation of a new corporation in the image and likeness of the $B B C$ left numerous debts, and its financing was trusted to a framework-mandate and a program-contract. Furthermore, a short time afterwards the model of financing was changed and advertising was ruled out of RTVE, a step clearly driven by the private television corporations (Azurmendi, 2007). The legal change, with new guarantees that were intended to ensure pluralism (López-Olano, 2015), was accompanied by a change in the management of the News Services, giving way to a new period of eight years in which credibility was recovered, achieving over 200 awards and recognitions.

However, with the political change in 2011 and the return of the Popular Party to government, the stability of public television was again eroded. In regards the budget, in spite of the guarantees presumably offered by the new legal framework, the RTVE Corporation again sunk into deficit: the successive cuts have again plunged it into financial suffocation. Moreover, the sharp fall in audience has meant it has lost its leadership to the competition of private channels, as Enrique Bustamante-Ramírez has denounced in various texts (Bustamante-Ramírez, 2013a, 2013b, 2014, 2015). As for the plurality and prestige of the news programs, the condemnations regarding manipulation and accusations of purges against independent journalists have led, for example, to the News Board calling for the area chief, Julio Somoano to resign (TVE, 2014). There have been studies that have shown a clearly tendentious and politicized focus of the news because RTVE began to be headed by a chairman 


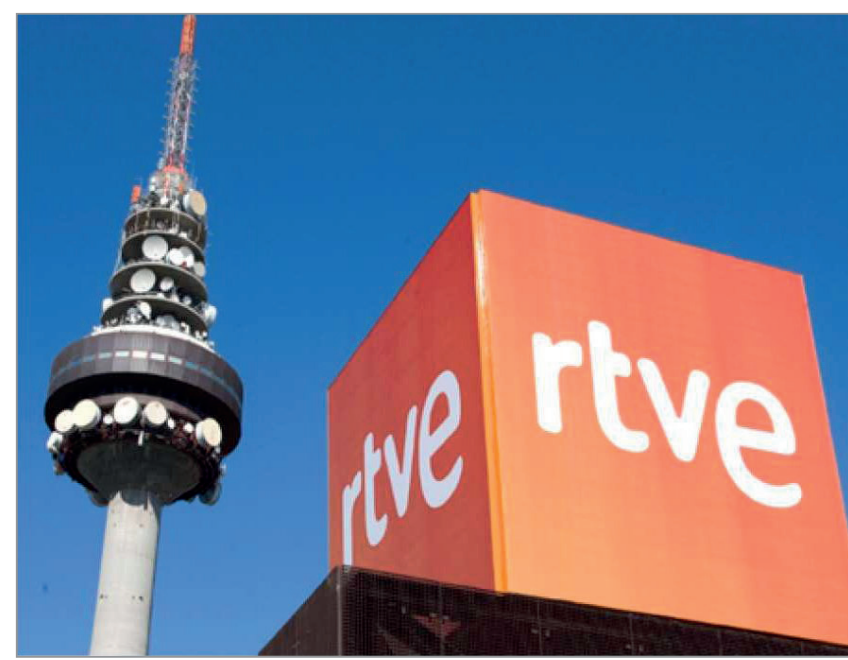

http://www.rtve.es

appointed unilaterally by the government (Soengas-Pérez; Rodríguez-Vázquez, 2014). All of the scandalous cases of continual interference by the government in the plurality of RTVE did not stop the then acting president of Spain, Mariano Rajoy, who was in the middle of the electoral campaign, from appealing to all of the political parties to find a model of consensus similar to that of the $B B C$ ( $L a$ vanguardia, 2016) in order to achieve independence for public television, both in terms of its plurality (in news coverage) and finance. After the elections of June, 2016, in Spain, the perspective was not encouraging. The continuity of the Popular Party in government did not ensure that this proposal to imitate the $B B C$ would become a real initiative to renew RTVE, which again has been on the edge of the abyss.

But it is not only RTVE that has problems. Spain has the most complicated regional audiovisual system in Europe (Richeri, 2005) due to the duplication of autonomous regional structures stemming from the Transition (period of time from Franco's dictatorship to democracy). The drop in audience has been the institutionalized norm in all cases since digital terrestrial television (DTT) took off, and the deficits are and always have been- rampant. Television stations with 25 years of broadcasting behind them have had massive layoffs, as with Telemadrid, or have directly shut down, as with Canal 9 RTVV. In regards the latter, after the political change in 2015, the Valencia government has been attempting to re-launch it, although for the time being there is no date for the service to resume.

\section{Hypothesis and aims of the research}

It is in this context of extended general crisis - whether exaggerated or not- in the public system of audiovisual media, that our investigation has been carried out. The main focus that concerns us is between the United Kingdom and Spain: the historical center of public service media, and the periphery of the system. We do not want to compare both public media systems, that is obviously an impossible mission. Within this atmosphere of change and renewal, we would like to point out the respective audiences' differences in conception and reception, with a priori we believe to be considerable. The model of television corporations does not reside only in their managers, its owners, or the governments that maintain them, but in all of the stakeholders as a whole (Freeman; Harrison; Wicks, 2007). We are going to deal with how the diverse perspective of what is surely the most important of these interest groups, the audience, affects the final result.

"Trust is at the center of the relationship with our audiences, a trust that must be earned each and every day" (EBU, 2012, p. 3).

We shall verify the different trusts and expectations that are generated by public television in the two systems which, as we have seen, are at the extremes of media maturity. We also consider that what the public expects from a medium, ends up having an influence on what they receive in exchange for this level of trust/distrust.

To illustrate the instability of RTVE, a single number is enough: from the beginning until now, the corporation has had 29 general directors/presidents. At the $B B C$, there have been only 14

\section{Method: Choice of corpus}

Our method of work is predominantly qualitative, based on carrying out semi-structured, in-depth individual interviews, asking oral questions about various matters related to considerations of public television, combined with our written questionnaire based on the social technology tool Delphi. The subjects chosen to take part formed two small but representative groups of young citizens within the potential audience of the respective British and Spanish media systems, with similar circumstances in order to be able to suitably compare the results. The two different sets have these characteristics:

Spain: A panel made up of 26 volunteers -15 women and 11 men- aged between 19 and 27, all of whom are university students. They are all Spanish. The interviews were conducted in March, 2016, on the University of Valencia campus.

United Kingdom: A panel made up of 22 volunteers -12 women and 10 men- aged between 18 and 35, all of whom are university students. All are residents in the United Kingdom, although six come from countries such as Ghana, Mauritania, and Cyprus. The interviews were conducted in February, 2016 , on the University of Roehampton (London) campus.

The age of the interviewees affects the results: it is amongst the youth that the audience of the $B B C$ has fallen, a common and universal phenomenon for all television corporations. This is recognized by the BBC Trust (2014), which also believes there has been a failure to attract persons of foreign origin and minority ethnics, which were represented on the panel (with six individuals). This random presence of a high number of international students is explained by the idiosyncrasy of British universities, which is different from Spanish ones, f.e. 
The video recordings of the interviews have been placed in a permanent location so they could be consulted and replicated. For citations, a system based on a code of minutes and seconds (00:00) was chosen, which corresponded to the beginning time of the interview of each of the volunteers. The university nature of the interviewees, as well as their youth, brings in a significant limitation as a representative sample, but we believe that this cross-section is interesting in that it is a sensitive group with a view to the future of the media.

https://goo.gl/dLVYqN

https://goo.gl/rrPddu

https://goo.gl/oznnkq

\section{Results}

The first of the questions in the in-depth interviews referred, in general, to what public television means to the interviewee. The replies from the British emphasized its importance, such as Charlotte D. (0:00):

"I guess [the] $B B C$ is the main social television in the UK, and they provide the most, what we consider the most important news and the most reliable programmes."

Also for Arin (0:00):

"It represents my country."

Maria H. said it was a symbol and a portrait of British life.

The initial evaluation of public television among Spanish youths was radically different. Practically nobody defended it, and some took a very tough line such as Tamara (00:04):

"Simply, when I think of public television the truth is I think of rubbish and junk TV. There is nothing good I can say about the matter, to tell the truth. It's a bit of a shame... but that's what I think."

Even so, many used the Spanish conditional to talk about what it should be, and not what it is. For example, Álvaro (0:00):

“Public television, I don't know, it's a citizens' right whether it's at a regional or national level. I don't know, it's a task that should be within the welfare state for society."

In writing, the students were also invited to evaluate public and private television in their respective countries on a scale of one (least quality) to 5 (most quality). Comparing the averages, we found what was to be expected: a better evaluation among the British than among the Spanish, but not as different as one may have thought after receiving the replies to the in-depth questions.

In the comparison with private televisions, both samples give scores below the public ones. That said, in Spain the difference in quality perceived between one and the other is narrower.

Table 1. Evaluation of public/private TV

\begin{tabular}{|l|c|c|}
\cline { 2 - 3 } \multicolumn{1}{c|}{} & British panel & Spanish panel \\
\hline Evaluation of public television & 3.80 & 2.70 \\
\hline Evaluation of private television & 2.95 & 2.50 \\
\hline
\end{tabular}

Table 2. Public TV qualities

\begin{tabular}{|l|c|c|}
\cline { 2 - 3 } \multicolumn{1}{c|}{} & British panel & Spanish panel \\
\hline Unbiased news & $1(\times 6)$ & $1(\times 11)$ \\
\hline Quality news & $2(\times 9)$ & $1(\times 7)$ \\
\hline Educational programs & $3(\times 6)$ & $3(\times 6)$ \\
\hline Accountability & $3(\times 5)$ & $2(\times 6)$ \\
\hline Transparency in administration & $6(\times 6)$ & $5(\times 5)$ \\
\hline Sufficiently attractive programs & $7(\times 6)$ & $7(\times 9)$ \\
\hline Non-commercial programs & $7(\times 5)$ & $6(\times 6)$ \\
\hline & British panel & Spanish panel \\
\hline Unbiased news & $1(\times 6)$ & $1(\times 11)$ \\
\hline Quality news & $2(\times 9)$ & $1(\times 7)$ \\
\hline Educational programs & $3(\times 6)$ & $3(\times 6)$ \\
\hline Accountability & $3(\times 5)$ & $2(\times 6)$ \\
\hline Transparency in administration & $6(\times 6)$ & $5(\times 5)$ \\
\hline Sufficiently attractive programs & $7(\times 6)$ & $7(\times 9)$ \\
\hline Non-commercial programs & $7(\times 5)$ & $6(\times 6)$ \\
\hline
\end{tabular}

\section{News and public television}

In the Delphi questionnaire, they were asked to put the qualities that public television should have in order, from lower to greater. Extracting the mode -in other words the most repeated order number- we got the results shown in Table 2.

Without a doubt, having impartial, quality news programs was clearly considered to be the most important quality that public television should have, for both the British and Spanish panels. Further down there were educational programs, and accountability, which as a factor more emphasized by the Spanish than by the British.

What the public expects from a medium, ends up having an influence on what they receive in exchange for this level of trust/distrust

In the oral interviews, they were also asked about the most significant quality in public television. In the interviews with students at Roehampton, they emphasized offering a good service of unbiased news, which is something that the $B B C$ is considered to be doing.

Noemí E. (0:55):

"BBC News is world-renowned, one of the best you can watch."

Helen C. (0:36):

"A lot of people love to see the $B B C$ to get information, because it is a kind of a reliable source."

And Paul C. (0:33):

"It's not biased, not highly influenced by any exterior forces."

In the replies to the same question asked orally in Spain, impartiality was also emphasized. However, it as done so 
Table 3. Evaluation of television corporations' dependence

\begin{tabular}{|l|c|c|}
\cline { 2 - 3 } \multicolumn{1}{c|}{} & $\begin{array}{c}\text { Independent of the } \\
\text { government }\end{array}$ & $\begin{array}{c}\text { Dependent on the } \\
\text { government }\end{array}$ \\
\hline$B B C$ & 9 & 13 \\
\hline$R T V E$ & 1 & 24 \\
\hline$R T V V$ & 1 & 25 \\
\hline
\end{tabular}

neutrally, without referring to the specific case of RTVE or autonomous regional channels, and they mentioned that it as not met.

Patricia (0:28):

"Well, above all, what they say should not be conditioned by anybody. It should all be objective and not in favor of anybody."

And Borja (0:30):

"The top quality... that the news programs should be impartial; currently I believe they aren't."

In the questionnaire, the questions were restricted to only two options: whether they believed the respective public televisions were independent of the government or not. In the case of Spain the questions were duplicated, specifying with respect to RTVE on a national level, and on an autonomous regional level corresponding to the geographical area, the now extinct RTVV (Table 3).

With the result devoid of nuances created by this question, we found that among the students in the United Kingdom the majority believed that the news programs were dependent, in spite of their open questions defending their objectivity and quality in general terms. Among the Spanish students, the reply was completely resounding.

\subsection{Pride and public television: Reactions to closure or hypothetical closure}

One of the last questions in the semi-structured interview referred to whether the respective public television was something about which one may feel proud. Among the British, in spite of some reticence, almost all agreed, and said yes.

Charlotte (1:31):

"I mean, proud of, yeah, I mean, they've made mistakes about them, but a lot of people make mistakes so, based on my own experience, they do a pretty good job."

Daniel L. (3:04):

"it's full of a lot of programs that are quite popular, so I guess people could be proud of it."

The foreign students, though they are resident in the United Kingdom, are those who are clearest, most certainly due to the contrast with their countries of origin.

Charalampia (1:15):

"I am not British, but if I was I would be proud of [the] $B B C$, yeah!"

The appeal to this sense of pride also works, though minimally, among the Spanish students, in spite of all the criticisms.
María (1:38):

"More or less proud."

Antonio (1:37):

"Yes, we can feel proud in general, but well, I'm going to make a little distinction: TVE is found lacking; it often commits the vice of not being impartial. And Canal 9, I personally think not, but due to the matter of not respecting that impartiality [...], but I do consider that we should have a Valencian public television to keep our culture alive, too".

But half of the interviewees opt for a resounding "no" as regards a feeling of pride, such as Juanjo M. (2:30):

"No, not at all. It's a shame."

The last of the questions posed a hypothetical scenario of closure of the public television corporation. The proposal for one panel or the other is different, obviously, since it is unthinkable in a system such as the British one, whereas in the Spanish panorama and specifically in Valencia, it is a fact that was carried out over four years ago. For the students at Roehampton, in general it was unconceivable.

In Spain the attitude is nearly always unfavorable. In general, there is no sense of pride, and although arguments are used to defend public television, neither the regional stations nor RTVE serve as an example

Daniel L. (3:40):

"I think people would be pretty annoyed, especially if they try to close it down and sell it off and privatize it."

The Valencian students are more familiar with this real closure, obviously. In general, there was a negative evaluation about the disappearance, the reason for which was given at the time as the economic crisis.

Naddia (1:53):

"I think we deserve one [television] for us, one in our place, let's say, and it should report on our things, our city."

Other interviewees understand the reasons, though they do not agree about the background.

Antonio (3:14):

"It seemed a bad decision to me, because it's a shame that the voice of Valencia should be shut off."

But even the most negative ones expressed the need to recover the service, such as Ricardo Peris (3:40):

"What l'd like now, if there is money in future, would be for RTVV to be refounded."

\section{Conclusions}

What the young audiences expect from their respective media systems is very different. This is the main conclusion 
that we can draw from the results obtained in the investigation. Pride for a wholly British cultural product still works as an argument among the students at Roehampton, even amongst the international students. On the other hand, in Spain the attitude was nearly always unfavorable. In general, there was not a sense of pride, and although arguments were used to defend public television, neither the regional ones nor RTVE served as an example. The difference as more obvious in the written replies when they were forced to score the quality of public television compared to private. In this indicator, the British gave a higher score but not as much as one might expect.

In the two panels, there was practically unanimity when underlining impartial news programs as the most important quality that must stand out in a public television corporation. In the interviews, the differences were again clear between the British - among whom despite critical voices, in general it was thought that good work was done at the $B B C$; and the Spanish- whose general opinion speaks of manipulation and biased news. It was again interesting to compare here with the information provided via the questionnaire. Among the British, in spite of the oral opinion in general defending the public television's news programs, 13 considered that they depended on the government, whereas only 9 defended their independence. The results from the Spanish were more obvious: in keeping with what they stated in the interviews, practically all of them think that neither RTVE nor RTVV are or have been independent of the government.

As for the hypothetical scenario of closure of public televisions, among the British this was improbable, whereas for the Spanish it corresponded to a real situation. Even so, in spite of the pessimism, the lack of trust, the lack of reasons for pride that until now have been provided by public television in Spain, there was a general feeling of a need to recover a public television. It was thought that the values it was believed to have should be recovered, and that the service should be re-established for all citizens.

\section{Notes}

1. All translations from Spanish are author's own.

\section{References}

Azurmendi, Ana (2007). La reforma de la televisión pública española. Valencia: Tirant lo Blanch. ISBN: 9788484569619

Azurmendi, Ana; Muñoz-Saldaña, Mercedes (2016). “Participación del público en televisiones públicas autonómicas: una propuesta a partir de la reforma 2016 de la BBC". El profesional de la información, v. 25, n. 5, pp. 803-813. https://doi.org/10.3145/epi.2016.sep.11

Barnett, Steven (2011). The rise and fall of TV journalism: Just wires and lights in a box?. London: Bloomsbury academic. ISBN: 9781849666480

Born, Georgina (2004). Uncertain vision: Birt, Dyke, and the reinvention of the $B B C$. London: Vintage. ISBN: 9780 099428930

Bustamante-Ramírez, Enrique (2013a). Historia de la radio y la televisión en España: Una asignatura pendiente de la democracia. Barcelona: Gedisa. ISBN: 9788497841634
Bustamante-Ramírez, Enrique (2013b). "El servei públic de RTVE sota el govern de Rajoy". L'espill, n. 43, pp. 110-118. http://roderic.uv.es/handle/10550/34617

Bustamante-Ramírez, Enrique (2014). "El caso español: mutación ideológica de modelos". In: Francés-Domènec, Miquel; Gavaldà-Roca, Josep; Llorca-Abad, Germán; Peris-Planes, Àlvar. La televisión de la crisis ante el abismo digital. Barcelona: Gedisa, pp. 15-30. ISBN: 9788497848091

Bustamante-Ramírez, Enrique (2015). "El servicio público en España: Manual de las malas prácticas". In: Marzal-Felici, Javier; Izquierdo-Castillo, Jessica; Casero-Ripollés, Andreu. La crisis de la televisión pública. El caso de RTVV y los retos de una nueva gobernanza. Bellaterra (Barcelona): UAB, pp. 23-38. ISBN: 9788415444701

Clementi, David (2016). A review of the governance and regulation of the BBC. London: Department for Culture, Media \& Sport.

https://www.gov.uk/government/publications/a-review-ofthe-governance-and-regulation-of-the- $B B C$

Cushion, Stephen (2012). Television journalism. Los Angeles, London: Sage Publications. ISBN: 9781446207413

Debrett, Mary (2014). Reinventing public service television for the digital future. Bristol: Intellect. ISBN: 9781 841503219

Department for Culture, Media and Sport (2015). BBC charter review public consultation. London: Department for Culture, Media \& Sport.

https://www.gov.uk/government/consultations/BBC-charterreview-public-consultation

Department for Culture, Media and Sport (2016). A BBC for the future: $A$ broadcaster of distinction. London: Department for Culture, Media \& Sport.

https://www.gov.uk/government/publications/a-BBC-forthe-future-a-broadcaster-of-distinction

Díaz, Lorenzo (2006). 50 años de TVE. Madrid: Alianza Editorial. ISBN: 9788420647463

EBU (2012). Empowering society. A declaration on the core values of public service media. European Broadcasting Union.

https://www.ebu.ch/files/live/sites/ebu/files/Publications/ EBU-Empowering-Society_EN.pdf

EBU (2015). Public service media contribution to society. European Broadcasting Union. Operating Eurovision and Euroradio.

https://www.ebu.ch/member-services/psm-contribution-society

Freedman, Des (2016a). "Decoding the BBC white paper". Our beeb. The future of the BBC, 12 May.

https://www.opendemocracy.net/ourbeeb/des-freedman/ decoding-BBC-white-paper

Freedman, Des (2016b). "The growing gap between private and public in European broadcasting". Our beeb. The future of the $B B C, 3$ February. https://goo.gl/rzcMgX

Freeman, Edward; Harrison, Jeffrey; Wicks, Andrew (2007). Managing for stakeholders: Survival, reputation and success. 
New Haven: Yale University Press. ISBN: 9780300125283

Habermas, Jürgen (1989). The structural transformation of the public sphere. Cambridge: Polity Press. ISBN: 9780 262581080

La vanguardia (2016). “Rajoy propone una televisión pública independiente como la BBC". La vanguardia. Televisión, 16 junio.

https://goo.gl/HF8Mzn

López-Olano, Carlos (2015). Los mecanismos de control de los informativos en las televisiones públicas. El caso de Canal 9. Ann Arbor (Michigan): ProQuest. ISBN: 9781339514260

Lowe, Gregory-Ferrell; Steemers, Jeanette (2012). Regaining the initiative for public service media. Gothenburg: Nordicom. ISBN: 9789186523336

https://goo.gl/5ekYx9

Mair, John; Tait, Richard; Keeble, Richard-Lance (2014). Is the $B B C$ in crisis?. Bury St. Edmunds, Suffolk: Abramis. ISBN: 9781845496210

Martinson, Jane (2016). "BBC white paper may be delayed until after EU referendum". The guardian, 4 March.

https://www.theguardian.com/media/2016/mar/04/BBCwhite-paper-may-be-delayed-until-after-eu-referendum

Palacio, Manuel (2012). La televisión durante la transición española. Madrid: Cátedra. ISBN: 9788437630687

Richeri, Giuseppe (1994). La transición de la televisión: análisis del audiovisual como empresa de comunicación. BarceIona: Bosch. ISBN: 9788476762820

Richeri, Giuseppe (2005). Le televisione pubbliche nelle regioni d'Europa. Rome: RAI. ISBN: 9788839713414
Rueda-Laffond, Juan-Carlos; Chicharro-Merayo, María-delMar (2006). La televisión en España, 1956-2006: política, consumo y cultura televisiva. Madrid: Fragua. ISBN: 97884 70742019

Schlesinger, Philip (1987). Putting 'reality' together: $B B C$ news. London: Methuen. ISBN: 9780416901900

Sehl, Annika; Cornia, Alessio; Nielsen, Rasmus-Kleis (2016). Public service news and digital media. Reuters Institute for the Study of Journalism.

https://goo.gl/1pgmxT

Soengas-Pérez, Xosé; Rodríguez-Vázquez, Ana-Isabel (2014). "El control gubernamental en RTVE y el pluralismo en los informativos". Estudios sobre el mensaje periodístico, v. 21, n.2, pp. $1225-1240$.

http://revistas.ucm.es/index.php/ESMP/article/view/50912/47256

Steemers, Jeanette (1998). Changing channels: The prospects for television in a digital world. Luton: John Libbey Media. ISBN: 9781860205446

Tambini, Daniel (2016). "Can the new charter protect BBC independence?". Inforrm's blog. The international forum for responsible media blog.

https://inforrm.wordpress.com/2016/02/03/can-the-newcharter-protect-BBC-independence-damian-tambini

Tracey, Michael (2014). "The concept of public value \& triumph of materialist modernity". In: Lowe, Gregory-FerreII; Martin, Fiona. The value of public service media. Gothenburg: Nordicom, pp. 87-104. ISBN: 9789186523848

TVE (2014). El CdI de TVE reclama un cambio en los informativos. Consejo de Informativos TVE.

http://extra.RTVE.es/cinftve/COMUNICADO_20140701.pdf

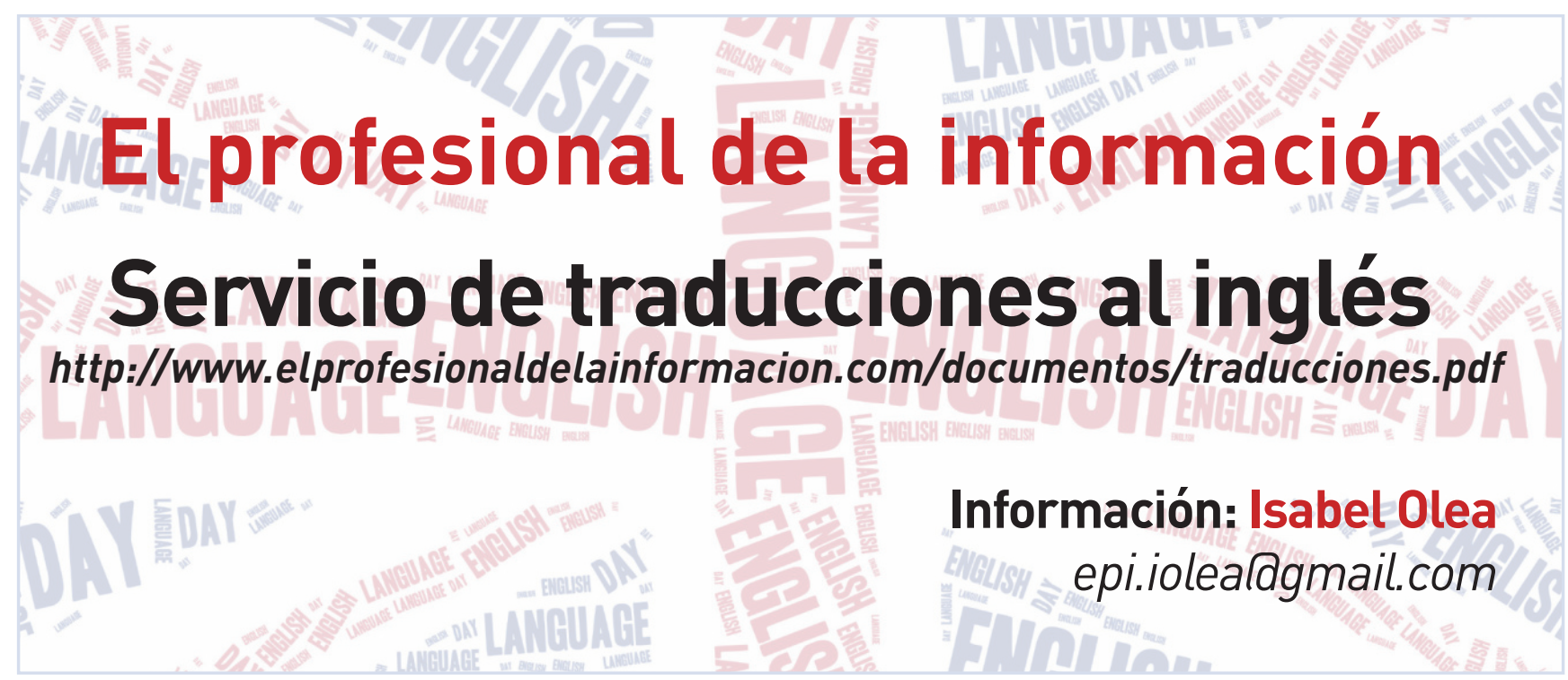

